\title{
How much total ovarian tissue can be removed without compromising ovarian function? An animal study
}

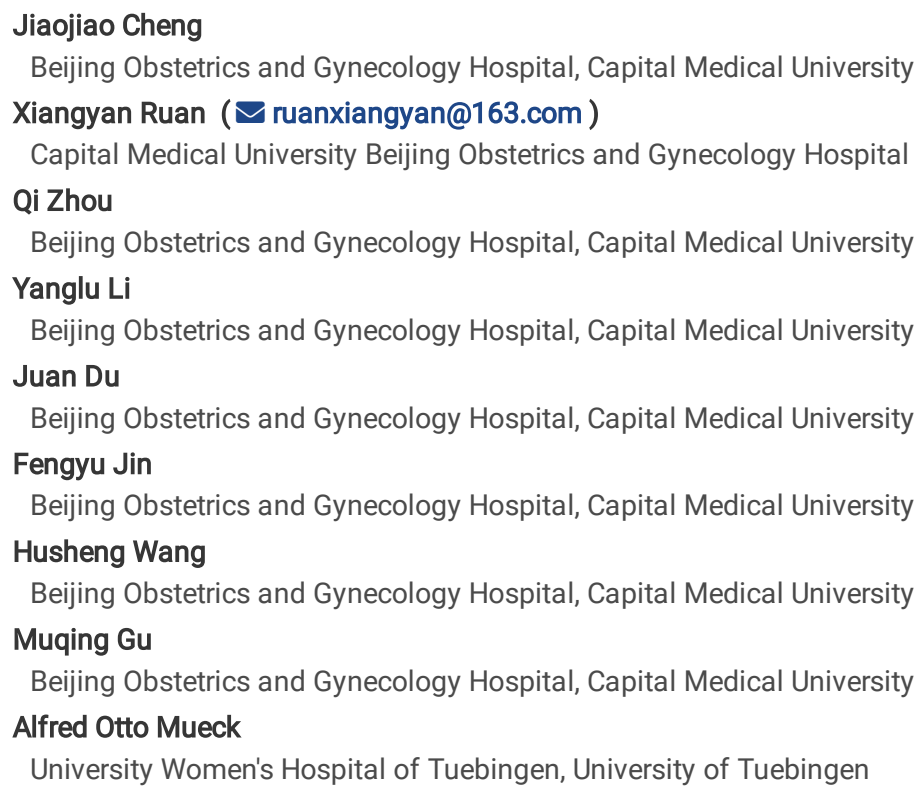

\section{Research}

Keywords: ovariectomy, ovarian function, ovarian tissue cryopreservation, premature ovarian insufficiency, fertility protection

Posted Date: February 17th, 2020

DOI: https://doi.org/10.21203/rs.2.23689/v1

License: (c) (1) This work is licensed under a Creative Commons Attribution 4.0 International License. Read Full License

Version of Record: A version of this preprint was published at Gynecological Endocrinology on May 5th, 2020. See the published version at https://doi.org/10.1080/09513590.2020.1760242. 


\section{Abstract}

Purpose Until now, it is not clear how much total ovarian tissue can be removed without affecting ovarian functions. Aim to investigate impact of stepwise removed ovarian tissue on endocrine hormone levels reflecting ovarian function, follicle morphology and weight in rats.

Methods The study was performed with six groups of animals, each consisting of six ten-week-old Sprague-Dawley rats. A blood test was performed on the day of surgery (baseline) and fortnightly thereafter to assess serum hormones reflecting ovarian function: estradiol (E2), progesterone (P), folliclestimulating hormone (FSH), anti-Müllerian hormone (AMH), inhibin B (INHB); weight was also assessed. The ovaries obtained from surgical resection and from the rats sacrificed 12 weeks after surgery were stained with hematoxylin-eosin. Surgeries in the groups; [\%] of remaining total ovarian tissue: Group 1 , non-ovariectomized [ $100 \%$ tissue]. Group 2, half of left ovary excised [ $75 \%$ tissue]. Group 3, left ovary excised [50\% tissue]. Group 4 , left ovary + half of right ovary excised [ $25 \%$ tissue]. Group 5 , left ovary + three quarters of right ovary excised [ $12.5 \%$ tissue]. Group 6 , bilateral ovariectomy [0\% tissue].

Results During the 12 weeks, group 4, 5 and 6 had higher FSH and lower AMH and INHB values compared to the control (group 1) ( $p<0.05$ ), but in group 4 production of $\mathrm{E} 2$ and $\mathrm{P}$ was not significantly different from control ( $p>0.05$ ). All ovarian function parameters completely stopped in group 5 , i.e. the same as the bilateral ovariectomized rats (group 6). Weight significantly increased in group $6(p<0.05)$. Follicle morphology at baseline and 12 weeks after surgery in groups 2-5 was not significantly different to the control.

Conclusions Our animal study confirms that removal of one ovary maintains the remaining ovarian tissue's potency for normal hormone production, as already suggested in clinical studies. However, to our knowledge, we demonstrate here for the first time that even up to $75 \%$ of total ovarian tissue can be removed without impact on $\mathrm{E} 2$ and $\mathrm{P}$ production, which if confirmed in women would mean that hazardous hormone replacement therapy is not required to avoid the negative consequences of hormone depletion.

\section{Introduction}

Ovaries play a fundamental role in fertility and steroidogenesis [1]. Removal of ovarian tissue may be necessary for pathological reasons, e.g. in patients with ovarian endometriosis and especially for ovarian tissue cryopreservation (OTC), an option for fertility protection in patients with certain cancers or in general to preserve ovarian function by ovarian tissue retransplantation (OTCT). Hormone replacement therapy (HRT) is recommended to avoid consequences of estradiol deficiency like climacteric symptoms and osteoporosis. However, many women are reluctant to take HRT due to the associated health risks, such as breast cancer, venous thrombosis, myocardial infarction and stroke [2]. Furthermore, HRT is contraindicated in some women, e.g. in patients with breast cancer who now often undergo OTC/OTCT for fertility protection. Indeed, OTCT may be not successful or may no longer be possible because of deterioration of the primary cancer and/or development of metastases, and these patients will develop POI with all its negative consequences. The prevalence of $\mathrm{POI}$ is as high as $7 \%$ in UK, which may be higher than $10 \%$ in China, of which $20-56 \%$ are caused by iatrogenic factors, and radiotherapy and/or chemotherapy can cause $\mathrm{POI}$ in $70-100 \%$ of women [3-6]. POI not only reduces women's fertility, but also causes various menopausal symptoms, osteoporosis, cardiovascular disease etc. Therefore, the question of how much total ovarian tissue, i.e. excisions in both ovaries, can be removed without stopping/finishing/compromising ovarian function, is of great practical interest.

Fertility potential is related to the total number and quality of primordial follicles remaining in the ovaries, the ovarian reserve [7], which can be estimated by serum levels of anti-Müllerian hormone (AMH) and inhibin B (INHB) $[8,9]$. OTC/OTCT is an emerging fertility and endocrine function preservation method, performed to avoid or treat POI [10,11]. Ovarian tissue is frozen before radio-/chemotherapy etc., and later retransplanted [12]. OTC/OTCT is recommended especially if gonadotoxic treatment cannot be delayed and is the exclusive method of preserving fertility in prepubertal girls [11,13]. It is now a widely performed procedure, especially in Europe, as seen in the "FertiPROTEKT network" [14,15]. More than 160 children have been born with this technology worldwide [16,17].

The "International Fertility Protection Center - Ovarian Tissue Cryobank of the Beijing Obstetrics and Gynecology Hospital, Capital Medical University, Beijing, China" is currently the first and only one in China, established with the help of international experts [18]. We have already cryopreserved more than 300 tissues within a short time and have published the first case of OTCT in China [19] and the Chinese guidelines for OTC/OTCT [20].

Within our research we have tried to optimize the protocol for OTC/OTCT [12] and gain new insights for further improvement, like this also is the aim of the present study. Up to now it was not clear how much ovarian tissue can be removed without compromising ovarian function. A systematic review [21] on OTC/OTCT summarized that unilateral oophorectomy was chosen in $11 \%$ of cases, partial decortication (removal of $1 / 3$ to $1 / 2$ of one ovary) in $79 \%$ and multiple biopsies in $8 \%$ of cases. Donnez et al. [17] and our Chinese guidelines [20] indicated that at least half of unilateral ovarian tissue should be cryopreserved; however, for severe cases (especially after cancer), removal of even more tissue may be necessary. In the European "FertiPROTEKT network", half an ovary was removed in 97\% [22]. Removal of one entire ovary is currently recommended for prepubertal girls due to the small size of the ovaries [23].

Obtaining multiple biopsy samples from one ovary has not been shown to compromise future hormone production [17]. However, we did not find any data about ovarian function if more ovarian tissue is removed. Thus, the objective of our study was to assess how much tissue can be removed without stopping ovarian function.

\section{Results}




\section{Changes in Weight}

Body weight of the six groups at baseline (day of surgery) and fortnightly during the 12 weeks' study is shown in Table 1 . Significant increases in weight in group 6 compared with group 1 were found $(p<0.05)$, there were no significant changes in all other groups.

Table 1

Body weight changes before and after surgery.

\begin{tabular}{|c|c|c|c|c|c|c|c|c|c|}
\hline Groups & $\mathbf{n}$ & $\begin{array}{l}\text { Percent of remaining total } \\
\text { ovarian tissue }\end{array}$ & $\begin{array}{l}\text { Body } \\
\text { weight/(g) } \\
\text { Baseline }\end{array}$ & $\begin{array}{l}\text { Body } \\
\text { weight/(g) } \\
2 \text { weeks }\end{array}$ & $\begin{array}{l}\text { Body } \\
\text { weight/(g) } \\
4 \text { weeks }\end{array}$ & $\begin{array}{l}\text { Body } \\
\text { weight/(g) } \\
6 \text { weeks }\end{array}$ & $\begin{array}{l}\text { Body } \\
\text { weight/(g) } \\
8 \text { weeks }\end{array}$ & $\begin{array}{l}\text { Body } \\
\text { weight/(g) } \\
10 \text { weeks }\end{array}$ & $\begin{array}{l}\text { Body } \\
\text { weight/(g) } \\
12 \text { weeks }\end{array}$ \\
\hline 1 & 6 & $100 \%$ & $\begin{array}{l}249.73 \pm \\
12.16\end{array}$ & $\begin{array}{l}267.90 \pm \\
11.05\end{array}$ & $\begin{array}{l}286.07 \pm \\
7.04\end{array}$ & $\begin{array}{l}299.30 \pm \\
12.27\end{array}$ & $\begin{array}{l}312.92 \pm \\
12.69\end{array}$ & $\begin{array}{l}316.27 \pm \\
16.17\end{array}$ & $\begin{array}{l}318.17 \pm \\
14.92\end{array}$ \\
\hline 2 & 6 & $75 \%$ & $\begin{array}{l}236.28 \pm \\
15.74\end{array}$ & $\begin{array}{l}265.63 \pm \\
18.03\end{array}$ & $\begin{array}{l}280.17 \pm \\
24.92\end{array}$ & $\begin{array}{l}295.47 \pm \\
19.35\end{array}$ & $\begin{array}{l}301.60 \pm \\
19.91\end{array}$ & $\begin{array}{l}304.07 \pm \\
18.57\end{array}$ & $\begin{array}{l}304.55 \pm \\
25.45\end{array}$ \\
\hline 3 & 6 & $50 \%$ & $\begin{array}{l}240.91 \pm \\
15.77\end{array}$ & $\begin{array}{l}267.10 \pm \\
19.20\end{array}$ & $\begin{array}{l}274.57 \pm \\
21.65\end{array}$ & $\begin{array}{l}296.30 \pm \\
26.27\end{array}$ & $\begin{array}{l}297.53 \pm \\
24.85\end{array}$ & $\begin{array}{l}303.85 \pm \\
27.59\end{array}$ & $\begin{array}{l}307.33 \pm \\
21.69\end{array}$ \\
\hline 4 & 6 & $25 \%$ & $\begin{array}{l}265.00 \pm \\
15.41\end{array}$ & $\begin{array}{l}279.27 \pm \\
28.89\end{array}$ & $\begin{array}{l}300.17 \pm \\
32.51\end{array}$ & $\begin{array}{l}330.13 \pm \\
38.95\end{array}$ & $\begin{array}{l}327.78 \pm \\
34.76\end{array}$ & $\begin{array}{l}330.75 \pm \\
35.02\end{array}$ & $\begin{array}{l}331.60 \pm \\
34.68\end{array}$ \\
\hline 5 & 6 & $12.5 \%$ & $\begin{array}{l}242.18 \pm \\
18.68\end{array}$ & $\begin{array}{l}282.22 \pm \\
33.02\end{array}$ & $\begin{array}{l}306.82 \pm \\
51.04\end{array}$ & $\begin{array}{l}322.53 \pm \\
59.89\end{array}$ & $\begin{array}{l}324.50 \pm \\
55.72\end{array}$ & $\begin{array}{l}332.60 \pm \\
62.72\end{array}$ & $\begin{array}{l}339.72 \pm \\
63.21\end{array}$ \\
\hline 6 & 6 & 0 & $\begin{array}{l}253.07 \pm \\
15.90\end{array}$ & $\begin{array}{l}313.07 \pm \\
33.37 *\end{array}$ & $\begin{array}{l}349.60 \pm \\
54.81^{*}\end{array}$ & $\begin{array}{l}379.22 \pm \\
67.46^{\star}\end{array}$ & $\begin{array}{l}380.03 \pm \\
74.96^{\star}\end{array}$ & $\begin{array}{l}390.23 \pm \\
88.12^{\star}\end{array}$ & $\begin{array}{l}399.00 \pm \\
86.63^{*}\end{array}$ \\
\hline \multicolumn{10}{|c|}{ The weight in the bilateral oophorectomy group (group 6) was higher than in control from week 2 to 12 after surgery. } \\
\hline \multicolumn{10}{|c|}{ Data are expressed as mean $\pm S D$} \\
\hline$\star P<0.0$ & & - & & & & & & & \\
\hline
\end{tabular}

\section{Assessment of FSH, E2 and P}

Serum E2, P and FSH values of the rats in the 6 groups are shown in Table 2 and Fig. 2. Group 5 and 6 had lower E2 and P values than group 1. However,

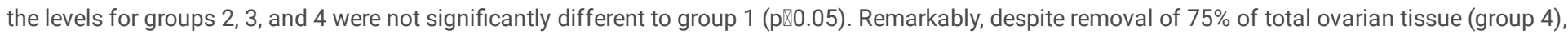
the production of E2 and P still was normal. There was a significant increase in FSH values in group 4, 5 and 6 compared to group 1, but no significant difference to the control in group 2 and 3 ( $\mathrm{p} \otimes 0.05)$. 
Table 2

E2, $\mathrm{P}$ and FSH changes before and after surgery.

\begin{tabular}{|c|c|c|c|c|c|c|c|c|c|}
\hline Groups & $\mathrm{n}$ & $\begin{array}{l}\text { Percent } \\
\text { of } \\
\text { remaining } \\
\text { ovarian } \\
\text { tissue }\end{array}$ & $\begin{array}{l}\mathrm{E} 2 /(\mathrm{pg} / \mathrm{ml}) \\
\text { Baseline }\end{array}$ & $\begin{array}{l}\text { E2/(pg/ml) } \\
2 \text { weeks }\end{array}$ & $\begin{array}{l}\text { E2/(pg/ml) } \\
4 \text { weeks }\end{array}$ & $\begin{array}{l}\mathrm{E} 2 /(\mathrm{pg} / \mathrm{ml}) \\
6 \text { weeks }\end{array}$ & $\begin{array}{l}\text { E2/(pg/ml) } \\
8 \text { weeks }\end{array}$ & $\begin{array}{l}\mathrm{E} 2 /(\mathrm{pg} / \mathrm{ml}) \\
10 \text { weeks }\end{array}$ & $\begin{array}{l}\text { E2/(pg/ml) } \\
12 \text { weeks }\end{array}$ \\
\hline 1 & 6 & $100 \%$ & $20.74 \pm 17.44$ & $26.57 \pm 13.38$ & $23.23 \pm 9.07$ & $21.45 \pm 9.09$ & $25.59 \pm 12.71$ & $25.52 \pm 15.39$ & $22.79 \pm 9.72$ \\
\hline 2 & 6 & $75 \%$ & $17.43 \pm 11.06$ & $24.37 \pm 16.62$ & $29.97 \pm 10.34$ & $33.49 \pm 10.53$ & $24.00 \pm 10.79$ & $23.36 \pm 13.24$ & $19.35 \pm 9.55$ \\
\hline 3 & 6 & $50 \%$ & $17.24 \pm 3.45$ & $25.03 \pm 8.38$ & $16.86 \pm 6.11$ & $24.55 \pm 15.19$ & $25.57 \pm 15.39$ & $16.35 \pm 7.98$ & $18.60 \pm 11.35$ \\
\hline 4 & 6 & $25 \%$ & $21.20 \pm 15.15$ & $15.98 \pm 11.54$ & $15.62 \pm 5.38$ & $16.04 \pm 11.10$ & $16.83 \pm 7.98$ & $16.38 \pm 11.93$ & $16.33 \pm 9.70$ \\
\hline 5 & 6 & $12.5 \%$ & $18.39 \pm 9.94$ & $6.06 \pm 1.26^{\star}$ & $5.35 \pm 0.57 *$ & $6.54 \pm 2.01^{\star}$ & $7.50 \pm 5.71 *$ & $7.50 \pm 5.71 *$ & $9.03 \pm 4.65^{\star}$ \\
\hline 6 & 6 & 0 & $18.84 \pm 11.57$ & $6.04 \pm 1.56^{\star}$ & $5.16 \pm 0.34^{\star}$ & $5.12 \pm 0.14^{\star}$ & $5.94 \pm 1.86^{*}$ & $5.94 \pm 1.86^{*}$ & $5.35 \pm 0.32 *$ \\
\hline Groups & $\mathbf{n}$ & $\begin{array}{l}\text { Percent } \\
\text { of } \\
\text { remaining } \\
\text { ovarian } \\
\text { tissue }\end{array}$ & $\begin{array}{l}\mathrm{P} /(\mathrm{ng} / \mathrm{ml}) \\
\text { Baseline }\end{array}$ & $\begin{array}{l}\mathrm{P} /(\mathrm{ng} / \mathrm{ml}) \\
2 \text { weeks }\end{array}$ & $\begin{array}{l}\mathrm{P} /(\mathrm{ng} / \mathrm{ml}) \\
4 \text { weeks }\end{array}$ & $\begin{array}{l}\mathrm{P} /(\mathrm{ng} / \mathrm{ml}) \\
6 \text { weeks }\end{array}$ & $\begin{array}{l}\mathrm{P} /(\mathrm{ng} / \mathrm{ml}) \\
8 \text { weeks }\end{array}$ & $\begin{array}{l}\mathrm{P} /(\mathrm{ng} / \mathrm{ml}) \\
10 \text { weeks }\end{array}$ & $\begin{array}{l}\mathrm{P} /(\mathrm{ng} / \mathrm{ml}) \\
12 \text { weeks }\end{array}$ \\
\hline 1 & 6 & $100 \%$ & $18.56 \pm 10.86$ & $23.31 \pm 9.02$ & $30.04 \pm 7.16$ & $20.99 \pm 8.25$ & $32.99 \pm 8.25$ & $24.34 \pm 8.37$ & $27.43 \pm 17.21$ \\
\hline 2 & 6 & $75 \%$ & $24.09 \pm 16.08$ & $22.61 \pm 10.94$ & $27.16 \pm 13.27$ & $20.30 \pm 8.14$ & $33.75 \pm 16.39$ & $27.37 \pm 10.88$ & $30.55 \pm 17.40$ \\
\hline 3 & 6 & $50 \%$ & $20.75 \pm 13.51$ & $15.71 \pm 5.55$ & $28.71 \pm 15.81$ & $19.43 \pm 6.73$ & $25.11 \pm 13.34$ & $25.68 \pm 6.74$ & $19.09 \pm 13.85$ \\
\hline 4 & 6 & $25 \%$ & $20.76 \pm 18.24$ & $21.58 \pm 15.01$ & $28.53 \pm 21.01$ & $15.48 \pm 1.00$ & $21.97 \pm 3.02$ & $17.87 \pm 5.50$ & $15.43 \pm 9.13$ \\
\hline 5 & 6 & $12.5 \%$ & $21.28 \pm 11.40$ & $12.61 \pm 2.10 *$ & $12.78 \pm 7.83^{*}$ & $7.15 \pm 2.41^{\star}$ & $10.42 \pm 3.97 *$ & $9.62 \pm 4.45^{\star}$ & $10.60 \pm 4.69 *$ \\
\hline 6 & 6 & 0 & $16.72 \pm 5.47$ & $9.37 \pm 5.54^{\star}$ & $11.01 \pm 9.55^{\star}$ & $6.08 \pm 2.95^{\star}$ & $9.84 \pm 4.56$ * & $10.34 \pm 5.20$ * & $9.00 \pm 1.73^{\star}$ \\
\hline Groups & $\mathbf{n}$ & $\begin{array}{l}\text { Percent } \\
\text { of } \\
\text { remaining } \\
\text { ovarian } \\
\text { tissue }\end{array}$ & $\begin{array}{l}\mathrm{FSH} /(\mathrm{mlU} / \mathrm{ml}) \\
\text { Baseline }\end{array}$ & $\begin{array}{l}\mathrm{FSH} /(\mathrm{mlU} / \mathrm{ml}) \\
2 \text { weeks }\end{array}$ & $\begin{array}{l}\mathrm{FSH} /(\mathrm{mlU} / \mathrm{ml}) \\
4 \text { weeks }\end{array}$ & $\begin{array}{l}\mathrm{FSH} /(\mathrm{mlU} / \mathrm{ml}) \\
6 \text { weeks }\end{array}$ & $\begin{array}{l}\mathrm{FSH} /(\mathrm{mlU} / \mathrm{ml}) \\
8 \text { weeks }\end{array}$ & $\begin{array}{l}\mathrm{FSH} /(\mathrm{mlU} / \mathrm{ml}) \\
10 \text { weeks }\end{array}$ & $\begin{array}{l}\mathrm{FSH} /(\mathrm{mlU} / \mathrm{ml}) \\
12 \text { weeks }\end{array}$ \\
\hline 1 & 6 & $100 \%$ & $2.22 \pm 0.77$ & $2.15 \pm 0.50$ & $2.20 \pm 0.33$ & $2.46 \pm 0.42$ & $2.17 \pm 0.48$ & $2.08 \pm 0.46$ & $1.95 \pm 0.28$ \\
\hline 2 & 6 & $75 \%$ & $1.99 \pm 0.30$ & $2.45 \pm 0.55$ & $2.27 \pm 0.26$ & $2.32 \pm 0.32$ & $2.18 \pm 0.46$ & $1.81 \pm 0.33$ & $2.04 \pm 0.32$ \\
\hline 3 & 6 & $50 \%$ & $1.98 \pm 0.20$ & $2.38 \pm 0.58$ & $2.49 \pm 0.77$ & $2.38 \pm 0.44$ & $2.43 \pm 0.68$ & $2.51 \pm 0.40$ & $2.28 \pm 0.71$ \\
\hline 4 & 6 & $25 \%$ & $1.95 \pm 0.56$ & $3.14 \pm 1.10$ * & $3.10 \pm 0.87 *$ & $2.95 \pm 0.25^{\star}$ & $3.15 \pm 0.50$ * & $2.66 \pm 0.57 *$ & $2.53 \pm 0.60$ * \\
\hline 5 & 6 & $12.5 \%$ & $2.04 \pm 0.21$ & $3.02 \pm 0.25^{\star}$ & $3.19 \pm 0.55^{\star}$ & $2.98 \pm 0.31^{\star}$ & $2.86 \pm 0.42 *$ & $2.97 \pm 0.76^{\star}$ & $3.12 \pm 0.12^{\star}$ \\
\hline 6 & 6 & 0 & $2.23 \pm 0.71$ & $3.11 \pm 0.57$ * & $2.99 \pm 0.71$ * & $3.02 \pm 0.60$ * & $2.96 \pm 0.66^{*}$ & $2.83 \pm 0.65^{\star}$ & $2.92 \pm 0.50$ * \\
\hline \multicolumn{10}{|c|}{ E2 and P values in groups 5 and 6 were lower than the control from week 2 to 12 after surgery. } \\
\hline \multicolumn{10}{|c|}{ FSH values in groups 4,5 and 6 were higher than the control from week 2 to 12 after surgery. } \\
\hline $\mathrm{Da}$ & & ed as $\mathrm{m}$ & $S D, * P<0.05$ & pared with th & trol group $(\mathrm{c}$ & 1). & & & \\
\hline
\end{tabular}

\section{Assessment of AMH and INHB}

Serum AMH, INHB values are shown in Table 3, Fig. 3. From 2 to 12 weeks after surgery, group 4, 5 and 6 had significantly lower AMH values than group 1 $(p<0.05)$, whereas the levels in group 2 and 3 were not statistically different from group 1 (pख0.05). At 2 and 4 weeks, group 5 and 6 , and from 6 to 12 weeks also group 4 had lower INHB values than group $1(p<0.05)$. The levels in group 2 and 3 were not statistically different from group 1 ( $\mathbb{\otimes} 0.05)$. 
Table 3

$\mathrm{AMH}$ and INHB changes before and after surgery.

\begin{tabular}{|c|c|c|c|c|c|c|c|c|c|}
\hline Groups & $\mathrm{n}$ & $\begin{array}{l}\text { Percent of } \\
\text { remaining } \\
\text { ovarian tissue }\end{array}$ & $\begin{array}{l}\text { AMH/(ng/ml) } \\
\text { Baseline }\end{array}$ & $\begin{array}{l}\mathrm{AMH} /(\mathrm{ng} / \mathrm{ml}) \\
2 \text { weeks }\end{array}$ & $\begin{array}{l}\mathrm{AMH} /(\mathrm{ng} / \mathrm{ml}) \\
4 \text { weeks }\end{array}$ & $\begin{array}{l}\mathrm{AMH} /(\mathrm{ng} / \mathrm{ml}) \\
6 \text { weeks }\end{array}$ & $\begin{array}{l}\mathrm{AMH} /(\mathrm{ng} / \mathrm{ml}) \\
8 \text { weeks }\end{array}$ & $\begin{array}{l}\mathrm{AMH} /(\mathrm{ng} / \mathrm{ml}) \\
10 \text { weeks }\end{array}$ & $\begin{array}{l}\mathrm{AMH} /(\mathrm{ng} / \mathrm{ml}) \\
12 \text { weeks }\end{array}$ \\
\hline 1 & 6 & $100 \%$ & $4.57 \pm 1.54$ & $3.95 \pm 0.90$ & $3.48 \pm 0.48$ & $2.87 \pm 0.57$ & $3.22 \pm 1.14$ & $2.46 \pm 0.91$ & $2.55 \pm 0.82$ \\
\hline 2 & 6 & $75 \%$ & $3.89 \pm 0.54$ & $3.32 \pm 0.70$ & $2.84 \pm 0.57$ & $2.77 \pm 0.66$ & $2.47 \pm 0.27$ & $2.34 \pm 0.23$ & $2.10 \pm 0.40$ \\
\hline 3 & 6 & $50 \%$ & $4.30 \pm 1.16$ & $2.77 \pm 0.19$ & $3.12 \pm 0.73$ & $2.01 \pm 0.51$ & $2.47 \pm 0.31$ & $2.05 \pm 0.55$ & $1.95 \pm 0.29$ \\
\hline 4 & 6 & $25 \%$ & $3.69 \pm 1.41$ & $0.85 \pm 0.46^{\star}$ & $0.93 \pm 0.62^{\star}$ & $0.69 \pm 0.53^{\star}$ & $0.73 \pm 0.40 *$ & $0.70 \pm 0.49 *$ & $0.48 \pm 0.43^{\star}$ \\
\hline 5 & 6 & $12.5 \%$ & $5.59 \pm 0.61$ & $0.55 \pm 1.06^{\star}$ & $0.67 \pm 1.40^{*}$ & $0.80 \pm 1.83^{\star}$ & $0.55 \pm 1.14^{\star}$ & $0.43 \pm 0.96^{*}$ & $0.38 \pm 0.80^{*}$ \\
\hline 6 & 6 & 0 & $4.71 \pm 0.90$ & $0.10 \pm 0.17 *$ & $0.18 \pm 0.38 *$ & $0.14 \pm 0.29 *$ & $0.17 \pm 0.34^{\star}$ & $0.16 \pm 0.31^{*}$ & $0.12 \pm 0.20$ * \\
\hline Groups & $\mathbf{n}$ & $\begin{array}{l}\text { Percent of } \\
\text { remaining } \\
\text { ovarian tissue }\end{array}$ & $\begin{array}{l}\text { INHB/(pg/ml) } \\
\text { Baseline }\end{array}$ & $\begin{array}{l}\text { INHB/(pg/ml) } \\
2 \text { weeks }\end{array}$ & $\begin{array}{l}\text { INHB } /(\mathrm{pg} / \mathrm{ml}) \\
4 \text { weeks }\end{array}$ & $\begin{array}{l}\text { INHB/(pg/ml) } \\
6 \text { weeks }\end{array}$ & $\begin{array}{l}\text { INHB/(pg/ml) } \\
8 \text { weeks }\end{array}$ & $\begin{array}{l}\text { INHB/(pg/ml) } \\
10 \text { weeks }\end{array}$ & $\begin{array}{l}\text { INHB/(pg/ml) } \\
12 \text { weeks }\end{array}$ \\
\hline 1 & 6 & $100 \%$ & $62.78 \pm 19.41$ & $79.51 \pm 38.91$ & $49.23 \pm 9.38$ & $47.66 \pm 12.13$ & $38.18 \pm 21.53$ & $31.06 \pm 13.18$ & $40.60 \pm 8.52$ \\
\hline 2 & 6 & $75 \%$ & $74.83 \pm 32.57$ & $88.20 \pm 58.44$ & $55.69 \pm 8.80$ & $60.72 \pm 30.08$ & $32.54 \pm 15.49$ & $32.00 \pm 17.81$ & $32.58 \pm 9.89$ \\
\hline 3 & 6 & $50 \%$ & $69.33 \pm 58.59$ & $50.09 \pm 12.10$ & $44.25 \pm 13.46$ & $34.64 \pm 15.56$ & $33.47 \pm 18.05$ & $21.14 \pm 12.90$ & $28.62 \pm 13.48$ \\
\hline 4 & 6 & $25 \%$ & $86.69 \pm 71.76$ & $74.40 \pm 40.18$ & $43.44 \pm 19.93$ & $\begin{array}{l}27.53 \pm \\
12.02^{\star}\end{array}$ & $9.51 \pm 3.00 *$ & $15.88 \pm 6.67 *$ & $\begin{array}{l}27.46 \pm \\
15.20^{*}\end{array}$ \\
\hline 5 & 6 & $12.5 \%$ & $48.12 \pm 23.80$ & $\begin{array}{l}31.07 \pm \\
16.01 *\end{array}$ & $\begin{array}{l}25.99 \pm \\
11.64^{\star}\end{array}$ & $18.05 \pm 3.66^{\star}$ & $4.64 \pm 2.27 *$ & $\begin{array}{l}12.03 \pm \\
10.10^{\star}\end{array}$ & $14.78 \pm 9.96^{*}$ \\
\hline 6 & 6 & 0 & $57.61 \pm 45.91$ & $\begin{array}{l}29.88 \pm \\
12.77^{\star}\end{array}$ & $\begin{array}{l}32.19 \pm \\
13.56^{*}\end{array}$ & $21.24 \pm 4.79 *$ & $4.50 \pm 1.92^{\star}$ & $\begin{array}{l}15.04 \pm \\
10.93^{\star}\end{array}$ & $10.82 \pm 7.32^{\star}$ \\
\hline \multicolumn{10}{|c|}{ AMH values in groups 4,5 , and 6 were lower than the control from week 2 to 12 weeks after surgery. } \\
\hline \multicolumn{10}{|c|}{ INHB values in group 5 and 6 were lower than the control group from 2 to 12 weeks after surgery. } \\
\hline \multicolumn{10}{|c|}{ INHB values in group 4 were lower than the control group from 6 to 12 weeks after surgery. } \\
\hline \multicolumn{10}{|c|}{ Data are expressed as mean $\pm S D * P<0.05$ compared with the control group (group 1). AMH, Anti-Mullerian hormone; INHB, Inhibin B } \\
\hline \multicolumn{10}{|c|}{ (A) Group 5, 6 had lower E2 levels than Group $1(P<.05)$ at 2, 4, 6, 8, 10, 12 weeks after surgery } \\
\hline \multicolumn{10}{|c|}{ (B) Group 5, 6 had lower P levels than Group $1(P<.05)$ at 2, 4, 6, 8, 10, 12 weeks after surgery } \\
\hline \multicolumn{10}{|c|}{ (C) Group 4, 5 and 6 had higher FSH levels than Groups $1(P<.05)$ at 2, 4, 6, 8, 10, 12 weeks after surgery. } \\
\hline \multicolumn{10}{|c|}{ *P<.05 vs. Group 1 (control). E2, estradiol; P, progestogen; FSH, follicle stimulating hormone. } \\
\hline \multicolumn{10}{|c|}{ (A) Group 4, 5 and 6 had lower AMH levels than Groups $1(P<.05)$ at 2, 4, 6, 8, 10, 12 weeks after surgery. } \\
\hline \multicolumn{10}{|c|}{ (B) Group 4, 5 and 6 had lower INHB levels than Group $1(P<.05)$ at $6,8,10,12$ weeks after surgery } \\
\hline \multicolumn{10}{|c|}{ AMH, Anti-Mullerian hormone; INHB, Inhibin B. } \\
\hline \multicolumn{10}{|c|}{ (B) 12 weeks after surgery control group } \\
\hline \multicolumn{10}{|c|}{ (C) 12 weeks after surgery group 2} \\
\hline \multicolumn{10}{|c|}{ (D) 12 weeks after surgery group 3} \\
\hline \multicolumn{10}{|c|}{ (E) 12 weeks after surgery group 4} \\
\hline \multicolumn{10}{|c|}{ (F) 12 weeks after surgery group 5} \\
\hline ck a & & w follicles. & bar equals 1 & $\mu \mathrm{m}$. The left & eacl & . & d $40 \mathrm{X}$ and th & & ied $100 x$ \\
\hline
\end{tabular}

\section{Ovarian volume and morphology}

The histological images of the ovaries stained by HE are shown in Fig. 4. All ovaries in the different groups showed normal follicle morphology (scale bar $=100 \mu \mathrm{m}$ ). Regarding ovarian volume, we did not find a significant difference between group 3 and control (there was also no significant difference in FSH and LH production), meaning no compensatory increase of the remaining ovary occurred. 


\section{Discussion}

\section{Main results and possible practical consequences}

In the present study, ovarian function of rats was investigated with a stepwise reduction of the total ovarian tissue from $0 \%$ (group 1 ) to $25 \%, 50 \%, 75 \%$, $82.5 \%$ and $100 \%$ in groups $2,3,4,5,6$, respectively. The most remarkable result is that excision of up to $75 \%$ of total ovarian tissue will still allow normal production of E2 and P. To our knowledge, has been shown for the first time in an animal model.

If this is also would be true for women undergoing removal of ovarian tissue for pathological reasons, e.g. ovarian endometriosis, in patients with cancer or to remove enough tissue for cryopreservation, the consequence would be that despite only $25 \%$ tissue remaining, HRT for treatment of estrogendeficiency consequences such as climacteric complaints or osteoporosis would not be necessary. Possible detrimental HRT risks like breast cancer, thromboembolism and stroke could therefore be avoided [2]. This is important when using OTC/OTCT for fertility protection, also for women not wanting fertility but with POI for other reasons [15-18,20].

\section{Hormone levels for assessment of ovarian function}

We found in our study that removal of $<75 \%$ of the total ovarian tissue (group $2,3,4$ ) maintains normal production of E2 and P (i.e. no significant difference to control), whereas FSH was significantly increased after $75 \%$ tissue excision (i.e. in group 4,5 and 6 ). It is well known that despite the negative feedback mechanisms within the HPO axis, E2 and P values can remain normal but FSH can increase, even in cases of higher E2 levels, especially during menopausal transition and often together with a decrease in INHB [24 - 26] .

From the AMH levels it can be suggested that in all experimental groups ( 2 to 6 ) there was a decrease in ovarian reserve directly after surgery. It has been suggested that serum $\mathrm{AMH}$ levels show the greatest sensitivity to ovarian insufficiency, particularly a strong correlation with the number of early antral follicles. This can explain the early decrease in AMH after excision of only $25 \%$ of total ovarian tissue. The decrease in INHB was later (starting 6 weeks after surgery) compared to $\mathrm{AMH}$ (starting 2 weeks after surgery) and was only seen if $75 \%$ and more of the total ovarian tissue was removed, i.e. in group 4,5 and 6 . Considering these results with INHB, the decrease is larger with the time after surgery and, as expected, with the amount of tissue removal.

We can conclude that ovarian reserve is starting to be significantly decreased after $75 \%$ removal, i.e. in group 4,5 and 6 . However, E2 and P are still produced in group 4 with normal values. This hormonal constellation can be clinically compared with women during hormonal transition where even pregnancy is possible with occasional ovulation and young women with a similar hormonal constellation (for example POI) can also become pregnant [27].

If fertility could be maintained after up to $75 \%$ excision of total ovarian tissue (which needs further research), our animal data strongly suggest that HRT can be avoided if also shown in human studies. In context with very new data investigating breast cancer risk during HRT use, which is mostly feared by patients and doctors, this result could be important. According to a recent meta-analysis including 58 studies [28], the number of additional breast cancer patients when using HRT is about five fold higher than calculated from earlier studies, with the striking result that even only one year of treatment with HRT can significantly increase breast cancer risk. This is especially important for OTC/OTCT, because for most patients retransplantation is only possible one or two even more years after cryopreservation.

\section{Ovaries' volume and morphology}

There was no significant difference in ovarian volume between group 3 and control. However, this may be due to the short observation time. This assessment was of interest because a compensatory increase in volume of the remaining ovary is known for women after unilateral oophorectomy [29].

No morphological differences in the follicles were seen in group 2-5 12 weeks after surgery compared with the control (Fig. 4). Because of the different ovarian volumes, the size of ovarian tissue sections is inconsistent and follicle count cannot be performed, but a follicular form can be seen in each group. This is well understood, as Jacques Donnez et al. Mentioned [17] that ovarian tissue extraction surgery itself does not cause damage to the follicles. The difference in hormone levels in our experiments is perhaps mainly due to the difference in volume of the remaining ovaries, as different ovarian volumes can have clinical implications in ovarian activity [30].

\section{Should unilateral oophorectomy be recommended?}

Unilateral oophorectomy is often performed in clinical practice. In our animal model, i.e. removal of $50 \%$ of total ovarian tissue in group 3, secretion of E2, $\mathrm{P}, \mathrm{FSH}, \mathrm{AMH}, \mathrm{INHB}$ was not affected. Clinical studies have shown a rather weak association of unilateral oophorectomy with ovarian endocrine and reserve function which was explained by compensatory growth of the remaining ovary [29,31 - 32]. It has been suggested that new primordial follicles may be generated from germline stem cells and oocytes develop from primitive germline cells harvested from women of reproductive age [33]. Normal values of FSH and INHB, as seen in group 3, may also be explained by greater feedback sensitivity in the HPO-axis of the remaining ovary.

Some studies suggest that unilateral oophorectomy is effective in restoring long term ovulation function in PCOS patients and after treatment of cancer [34,35]. It is reassuring that women with only one ovary do not seem to have a reduced potential to conceive, either naturally or via IVF [35]. However, the outcomes of unilateral oophorectomy may differ in these populations and removing one ovary can be a strong risk factor for early menopause [32], particularly before the age of 35 years. It can adversely affect the fertility potential of women who already have reduced ovarian reserve and multiple risk factors for early menopause [34]. Despite our encouraging experimental results, further research is needed for these patients, and unilateral oophorectomy should not be currently recommended. 


\section{Changes in Weight}

Among the five experimental groups, only the bilateral oophorectomy group (group 6) showed significant changes in weight - a significant gain compared to control (Table 1). This is consistent with clinical findings in women with weight increase after menopause [36]. This may be due to decreased estrogen production causing changes in metabolic function (deterioration in lipid and glucose metabolism) with changes in the energy budget. In our study, all rats in group 6 were acutely postmenopausal because of "surgical menopause". Increased weight was also observed in group 5, but was not significant. We speculate that this was not because of $17.5 \%$ ovarian tissue remaining, but because they were postmenopausal since E2 and P significantly decreased and FSH increased, comparable to group 6.

\section{Strength and Limitations}

This study is the first to determine the effects of stepwise removal of ovarian tissue on endocrine and reserve function in rats. It may have been possible to obtain more information with more groups, e.g. testing $32.5 \%$ ovarian tissue. However, after discussion with our ethical committee, we wanted to limit the number of animals used, and we doubt that more relevant information would have been obtained by testing more groups. And we designed 6 rats in each group according to the suggestions from the experts of ethical committee. We investigated the early stage impact of stepwise removed ovarian tissue, so we only observed 12 weeks after surgery. Further long-term observation of ovarian function could be of interest, especially for group 4, where we could expect that not only the production of E2 and P is maintained despite of $75 \%$ removal of total ovarian tissue, but other parameters could recover, also leading to maintenance of fertility.

\section{Summary and Conclusion}

Excision of ovarian tissue is necessary for women wanting cryopreservation and later retransplantation to preserve fertility and for pathological changes in the ovaries. Function of the remaining tissue is wanted because retransplantation of tissue may not be successful. HRT to treat and prevent estrogen deficiency sequelae is often rejected because of potential risks or may not be possible due to contraindications.

Our animal study confirms that removal of one ovary does not affect the secretion of E2, P, FSH, AMH and INHB, i.e. the function of ovarian tissue is maintained. However, to our knowledge we have demonstrated for the first time that even removal of up to $75 \%$ of the total ovarian tissue can still maintain normal production of E2 and P. If confirmed in women, risky HRT could be avoided. It may be appropriate in the future to increase the excision volume of ovarian tissue for cryoconservation to achieve enough ovarian potency after retransplantation, since chemotherapy can lead to severe POI. Further research is needed to investigate if not only E2/P production, but also fertility can be maintained with only $25 \%$ remaining total ovarian tissue.

\section{Materials And Methods Animals and Grouping}

Healthy adult female specific-pathogen-free-grade Sprague-Dawley rats aged 10 weeks and $230 \sim 270 \mathrm{~g}$ weight were obtained from Beijing Vital River Laboratory Animal Technology Company Limited (Beijing, China); animal license SCXK (Beijing) 2011-0012. The experiments were performed at the Laboratory Animal Centre, Capital Medical University, China. The animals were housed in groups of 3 per cage $(60 \times 50 \times 22 \mathrm{~cm}$, Insight Ltda, China) and were maintained under standard laboratory conditions (12-hour light/dark cycles; $20 \sim 24^{\circ} \mathrm{C}$; relative humidity: 50\% 70\%). Vaginal smears were performed after acclimatization for 10 days, estrous cycle was determined and rats with a normal estrous cycle were included. In total 36 rats were randomly divided into six groups and the 12-week study was performed prospectively.

\section{Surgery}

Group 1, non-ovariectomized. Group 2, half of left ovary excised. Group 3, left ovary excised. Group 4, left ovary + half of right ovary excised. Group 5, left ovary + three quarters of right ovary excised. Group 6, bilateral ovariectomy. The animals were anesthetized with intraperitoneally administered Nembutal ${ }^{\circledR}, 40 \mathrm{mg} / \mathrm{kg}$ body weight. For tissue removal in group 2 (Fig. 1A), the $4-0$ nylon-suture was placed in the middle of the ovary volume, and half the ovaries were excised. For group 3, the suture was placed on the ovarian pedicle and the entire left ovary was removed. The excision method was similar for groups 4, 5 (Fig. 1B) and 6, and for group 5, the $4-0$ nylon-suture was placed in the one quarter of the ovary volume near ovarian pedicle, and three quarers of the ovaries were excised. The skin and muscle wall were then sutured with silk thread. 12 weeks after surgery, the animals were sacrificed with overdose anesthetized with intraperitoneally administered Nembutal ${ }^{\circledR}, 100 \mathrm{mg} / \mathrm{kg}$ body weight. The suture was placed on the ovarian pedicle and the residual ovary was removed, only group 6 rats have no remaining ovarian tissue.

\section{Assessment of serum E2, P, FSH, AMH, INHB}

Blood was collected from the venous sinus. After ten days, the first ovarian partial resection was performed and blood was collected every 2 weeks after anesthesia. The samples were held at room temperature for $15 \mathrm{~min}$, centrifuged at $2000 \mathrm{rpm}$ for $20 \mathrm{~min}$, and the supernatant was stored at $-80^{\circ} \mathrm{C}$. Estradiol (E2), progesterone (P), FSH, AMH and INHB levels were quantified using estradiol electrochemiluminescence (ECL) kit (Roche Diagnostics $\mathrm{GmbH}$, Germany), progesterone ECL kit (Roche Diagnostics GmbH, Germany), FSH ECL kit (Roche Diagnostics GmbH, Germany), AMH ECL kit (Roche Diagnostics $\mathrm{GmbH}$, Germany), rat INHB enzyme-linked immunosorbent assays (ELISAs) kit (Wuhan Huamei Biological Engineering Co., Ltd., China), respectively. All analyses were performed without knowledge of the grouping. E2, progesterone, FSH and AMH were read on the Roche ECL Automatic Immunoassay Analyzer Cobas e 411 (Roche Diagnostics GmbH, Germany). INHB was read on Multiskan FC type microplate reader (Thermo Fisher Scientific Instrument Co., Ltd., Shanghai, China). The intra-assay and inter-assay coefficient of variations for estradiol were $4.1 \%$ and $5.4 \%$, respectively.

Page $7 / 12$ 
Intra-assay and inter-assay coefficient of variations were as follows: for progesterone $2.2 \%$ and $5.0 \%$, for $\mathrm{FSH} 1.7 \%$ and $4.7 \%$, for $\mathrm{AMH} 1.3 \%$ and $3.8 \%$, respectively, for INHB both were $<15 \%$.

\section{Assessment of ovarian morphology}

The fixed ovaries were transferred to $10 \%$ formalin, embedded in paraffin wax, serial sectioned ( $5 \mu \mathrm{m})$, stained with hematoxylin and eosin (HE) and photographed by light microscopy (Leica, Germany). Images were captured by an Olympus DP controller and manager (Leica, Germany) at 100x magnification.

\section{Statistical Analysis}

All data were analyzed using Statistical Package for the Social Sciences version 23.0 (SPSS, Chicago, IL, USA). Values are means \pm standard deviation (SD). Mauchly's Test of Sphericity was used to determine if there was a correlation between the results at different time points of repeated measurements. $\mathrm{P}<0.05$ meant there was a correlation between repeated measurement data which cannot be processed by one-way analysis of variance, and multivariate analysis of variance was needed. In our study, Mauchly's Test of Sphericity of body weight, E2, P, FSH, AMH, and INHB were P< 0.05 . Thus, all data were analyzed by repeated measures analysis of variance and thereafter multivariate analysis of variance. If a significant overall difference was shown, the post hoc LSD test was used for further comparisons. $P<0.05$ was considered statistically significant.

\section{Abbreviations}

POI: Premature Ovarian Insufficiency; OTC: Ovarian Tissue Cryopreservation; OTCT: Ovarian Tissue Cryopreservation and Retransplantation; E2: estradiol; P: progesterone; FSH: Follicle Stimulating Hormone; AMH: Anti-müllerian hormone; INHB: Inhibin B; HRT: Hormone Replacement Treatment; HPO: Hypothalamic Pituitary Ovary; IVF: In-vitro Fertilization; LSD: Least-significant difference; SD Standard Deviation; HE: Hematoxylin and Eosin

\section{Declarations}

\section{Ethics approval and consent to participate}

All applicable institutional guidelines for the care and use of animals were followed. Animal studies were performed in accordance with the guidelines approved by the Animal Experiments and Experimental Animal Welfare Committee of Capital Medical University, China on 25, October, 2018 (protocol number AEEI-2018-163). These guidelines comply with the ARRIVE guidelines, in accordance with the National Institute of Health guide for the care and use of laboratory animals (NIH Publications No.8023, 1978).

\section{Consent for publication}

Not applicable

\section{Availability of data and materials}

The datasets used and/or analysed during the current study are available from the corresponding author on reasonable request.

\section{Competing interests}

The authors declare that they have no competing interests.

\section{Funding}

This study was supported by Beijing Municipal Administration of Hospitals' Ascent Plan (DFL20181401); Beijing Municipal Administration of Hospitals Clinical medicine Development of special funding support (XMLX201710); Medical Health Technology Innovation and Talent Training Special Fund (2017041900004, 2018042000001, 2018042000002); Beijing Natural Science Foundation (7202047).

\section{Authors' contributions}

JC: Experimental design, Project development, Data collection, Data analysis, Manuscript writing. XR: Experimental design and project development. QZ, YL, JD, FJ, HW, MG: Data collection and Data analysis. AOM: Experimental design, Manuscript modification. All authors read and approved the final manuscript. 


\section{Acknowledgements}

We gratefully acknowledge Xingming Li, associate professor, PhD, School of Health Administration and Education, Capital Medical University, Beijing, for his support in statistical analysis.

\section{References}

1. Donnez J, Dolmans MM. The ovary: from conception to death. Fertil S 2017;108:594-5. DOI: 10.1016/j.fertnstert.2017.08.031

2. Rossouw JE, Anderson GL, Prentice RL, LaCroix AZ, Kooperberg C, Stefanick ML et al.. Risks and benefits of estrogen plus progestin in healthy postmenopausal women: principal results From the Women's Health Initiative randomized controlled trial. JAMA. 2002;288:321-33. DOI: 10.1001/jama.288.3.321

3. Webber L, Davies M, Anderson R, Bartlett J, Braat D, Cartwright B et al.. ESHRE Guideline: management of women with premature ovarian insufficiency. Hum R 2016;31:926-37. DOI: 10.1093/humrep/dew027

4. Lew R. Natural history of ovarian function including assessment of ovarian reserve and premature ovarian failure. Best Pract Res Clin Obstet Gynaecol. 2019;55:2-13. DOI: 10.1016/j.bpobgyn.2018.05.005

5. Tsiligiannis S, Panay N, Stevenson JC. Premature Ovarian Insufficiency and Long-Term Health Consequences. Curr Vasc P 2019;17:604-9. DOI: $10.2174 / 1570161117666190122101611$

6. Mishra GD, Chung HF, Cano A, Chedraui P, Goulis DG, Lopes P et al.. EMAS position statement: Predictors of premature and early natural menopause. M 2019;123:82-8. DOI: 10.1016/j.maturitas.2019.03.008

7. Broer SL, Broekmans FJ, Laven JS, Fauser BC. Anti-Mullerian hormone: ovarian reserve testing and its potential clinical implications. Hum Reprod U 2014;20:688-701. DOI: 10.1093/humupd/dmu020

8. Tinkanen H, Blauer M, Laippala P, Tuohimaa P, Kujansuu E. Correlation between serum inhibin B and other indicators of the ovarian function. Eur $\mathrm{J}$ Obstet Gynecol Reprod Biol. 2001;94:109-13. DOI: 10.1016/s0301-2115(00)00319-5

9. Testing and interpreting measures of ovarian reserve: a committee opinion. Fertil S 2015;103:e9-17. DOI: 10.1016/j.fertnstert.2014.12.093

10. Andersen CY, Bollerup AC, Kristensen SG. Defining quality assurance and quality control measures in connection with ovarian tissue cryopreservation and transplantation: a call to action. Hum R 2018;33:1201-4. DOI: 10.1093/humrep/dey105

11. Amorim CA, Leonel E, Afifi Y, Coomarasamy A, Fishel S. Cryostorage and retransplantation of ovarian tissue as an infertility treatment. Best Pract Res Clin Endocrinol Metab. 2019;33:89-102. DOI: 10.1016/j.beem.2018.09.002

12. Li Y, Ruan X, Liebenthron J, Montag M, Zhou Q, Kong W et al.. Ovarian tissue cryopreservation for patients with premature ovary insufficiency caused by cancer treatment: optimal protocol. C 2019;22:383-9. DOI: 10.1080/13697137.2018.1554644

13. Corkum KS, Laronda MM, Rowell EE. A review of reported surgical techniques in fertility preservation for prepubertal and adolescent females facing a fertility threatening diagnosis or treatment. Am J S 2017;214:695-700. DOI: 10.1016/j.amjsurg.2017.06.013

14. Beckmann MW, Lotz L, Toth B, Baston-Bust DM, Fehm T, Frambach T et al.. Concept Paper on the Technique of Cryopreservation, Removal and Transplantation of Ovarian Tissue for Fertility Preservation. Geburtshilfe Frauenheilkd. 2019;79:53-62. D0I: 10.1055/a-0664-8619

15. von Wolff M, Sanger N, Liebenthron J. Is Ovarian Tissue Cryopreservation and Transplantation Still Experimental? It Is a Matter of Female Age and Type of Cancer. J Clin O 2018:01800425. DOI: 10.1200/JC0.18.00425

16. Liebenthron J, Montag M, Reinsberg J, Koster M, Isachenko V, van der Ven K et al.. Overnight ovarian tissue transportation for centralized cryobanking: a feasible option. Reprod Biomed O 2019;38:740-9. DOI: 10.1016/j.rbmo.2019.01.006

17. Donnez J, Dolmans MM. Fertility Preservation in Women. N Engl J Med. 2017;377:1657-65. DOI: 10.1056/NEJMra1614676

18. Liebenthron J, Montag M. Chapter 15 Development of a Nationwide Network for Ovarian Tissue Cryopreservation. Methods Mol Biol. 2017;1568:20520. DOI: 10.1007/978-1-4939-6828-2_15

19. Ruan X, Du J, Korell M, Kong W, Lu D, Jin F et al.. Case report of the first successful cryopreserved ovarian tissue retransplantation in China. C 2018;21:613-6. DOI: 10.1080/13697137.2018.1514005

20. Ruan X. Chinese Society of Gynecological Endocrinology affiliated to the International Society of Gynecological Endocrinology Guideline for Ovarian Tissue Cryopreservation and Transplantation. Gynecol E 2018;34:1005-10. DOI: 10.1080/09513590.2018.1488957

21. Beckmann MW, Dittrich R, Findeklee S, Lotz L. Surgical Aspects of Ovarian Tissue Removal and Ovarian Tissue Transplantation for Fertility Preservation. Geburtshilfe Frauenheilkd. 2016;76:1057-64. DOI: 10.1055/s-0042-115017

22. von Wolff M, Dittrich R, Liebenthron J, Nawroth F, Schuring AN, Bruckner T et al.. Fertility-preservation counselling and treatment for medical reasons: data from a multinational network of over 5000 women. Reprod Biomed 0 2015;31:605-12. DOI: 10.1016/j.rbmo.2015.07.013

23. von Wolff M, Germeyer A, Liebenthron J, Korell M, Nawroth F. Practical recommendations for fertility preservation in women by the FertiPROTEKT network. Part II: fertility preservation techniques. Arch Gynecol O 2018;297:257-67. DOI: 10.1007/s00404-017-4595-2

24. Hall JE. Endocrinology of the Menopause. Endocrinol Metab Clin North Am. 2015;44:485-96. DOI: 10.1016/j.ecl.2015.05.010 
25. Burger HG, Hale GE, Robertson DM, Dennerstein L. A review of hormonal changes during the menopausal transition: focus on findings from the Melbourne Women's Midlife Health Project. Hum Reprod U 2007;13:559-65. DOI: 10.1093/humupd/dmm020

26. Gracia CR, Sammel MD, Freeman EW, Lin H, Langan E, Kapoor S et al.. Defining menopause status: creation of a new definition to identify the early changes of the menopausal transition. M 2005;12:128-35. DOI: 10.1097/00042192-200512020-00005

27. Younis JS, Naoum I, Salem N, Perlitz Y, Izhaki I. The impact of unilateral oophorectomy on ovarian reserve in assisted reproduction: a systematic review and meta-analysis. BJOG. 2018;125:26-35. DOI: 10.1111/1471-0528.14913

28. Type and timing of menopausal hormone therapy and breast cancer risk: individual participant meta-analysis of the worldwide epidemiological evidence. L 2019;394:1159-68. DOI: 10.1016/S0140-6736(19)31709-X

29. Khan Z, Gada RP, Tabbaa ZM, Laughlin-Tommaso SK, Jensen JR, Coddington CR et al.. Unilateral oophorectomy results in compensatory follicular recruitment in the remaining ovary at time of ovarian stimulation for in vitro fertilization. Fertil S 2014;101:722-7. DOI:

10.1016/j.fertnstert.2013.11.019

30. Lass A, Brinsden P. The role of ovarian volume in reproductive medicine. Hum Reprod U 1999;5:256-66. DOI: 10.1093/humupd/5.3.256

31. Roth JJ, Jones RE. A single ovary of Anolis carolinensis responds more to exogenous gonadotropin if the contralateral ovary is absent. Gen Comp Endocrinol. 1992;85:486-92. DOI: 10.1016/0016-6480(92)90093-y

32. Coccia ME, Rizzello F, Mariani G, Bulletti C, Palagiano A, Scarselli G. Ovarian surgery for bilateral endometriomas influences age at menopause. Hum R 2011;26:3000-7. DOI: 10.1093/humrep/der286

33. White YA, Woods DC, Takai Y, Ishihara O, Seki H, Tilly JL. Oocyte formation by mitotically active germ cells purified from ovaries of reproductive-age women. Nat M 2012;18:413-21. DOI: 10.1038/nm.2669

34. Bouchlariotou S, Tsikouras P, Rosing B, Neulen J. Women with one ovary in assisted reproduction technologies: a review of the literature. Arch Gynecol O 2012;286:1041-7. DOI: 10.1007/s00404-012-2477-1

35. Schmidt KT, Nyboe AA, Greve T, Ernst E, Loft A, Yding AC. Fertility in cancer patients after cryopreservation of one ovary. Reprod Biomed 0 2013;26:272-9. DOI: 10.1016/j.rbmo.2012.12.001

36. Lizcano F, Guzman G. Estrogen Deficiency and the Origin of Obesity during Menopause. Biomed Res I 2014;2014:757461. DOI: $10.1155 / 2014 / 757461$

\section{Figures}
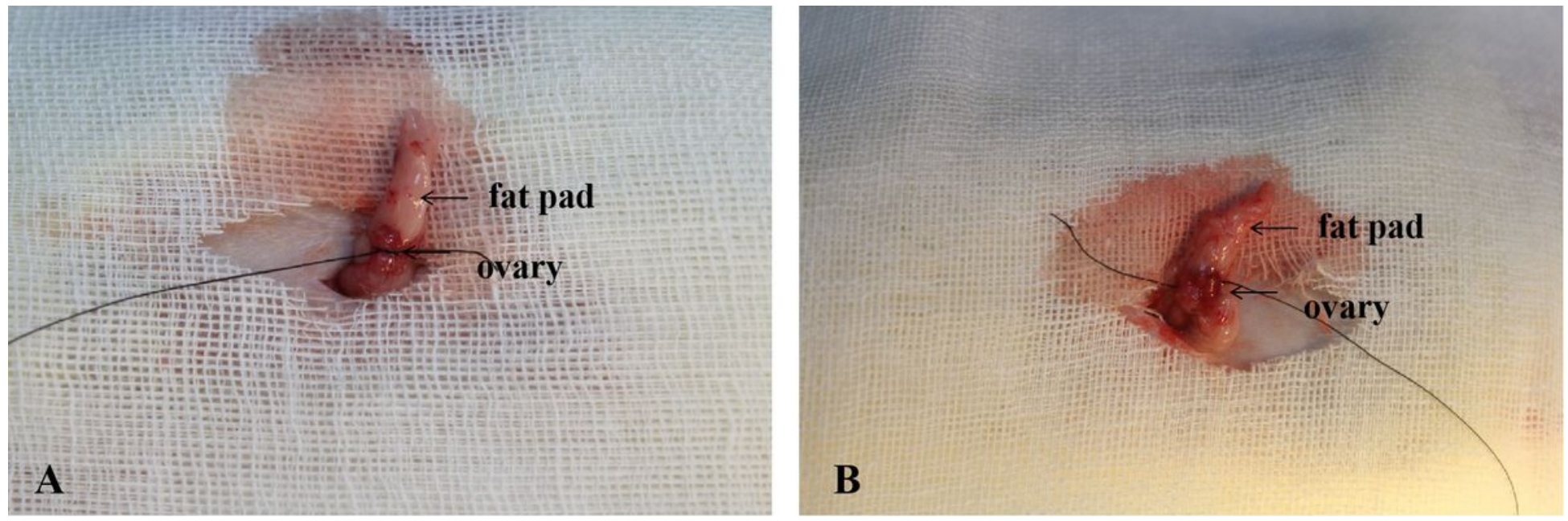

\section{Figure 1}

Ovarian surgeries (A) The 4-0 nylon suture was placed in the middle of the ovary volume, and after gentle tightening, $50 \%$ of the ovaries on the free side were removed. (B) The 4-0 nylon suture was placed in the right ovary close to a quarter of the ovary pedicle, and three-quarters of the ovarian tissue on the free side were removed. 
A $\quad$ B

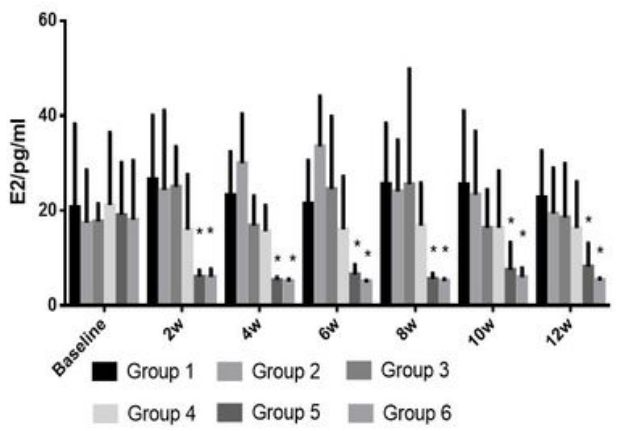

C

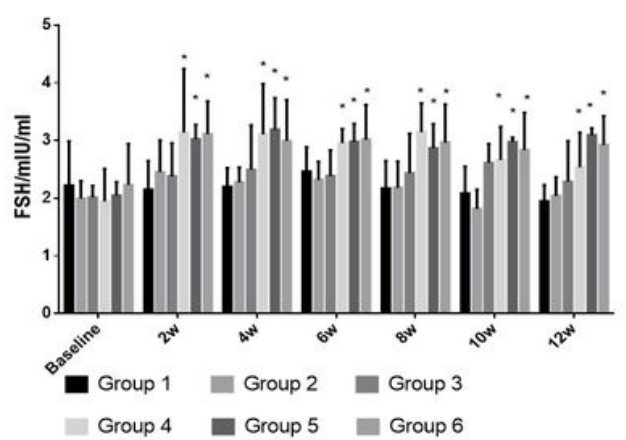

Figure 2

E2, P and FSH levels. 25\% remaining total ovarian tissue (group 4) still shows normal production of E2, P. (A) Group 5, 6 had lower E2 levels than Group 1 $(P<.05)$ at $2,4,6,8,10,12$ weeks after surgery $(B)$ Group 5,6 had lower $P$ levels than Group $1(P<.05)$ at $2,4,6,8,10,12$ weeks after surgery $(C)$ Group 4,5 and 6 had higher FSH levels than Groups $1(\mathrm{P}<.05)$ at 2, 4, 6, 8, 10, 12 weeks after surgery. *P凶.05 vs. Group 1 (control). E2, estradiol; P, progestogen; FSH, follicle stimulating hormone.

A

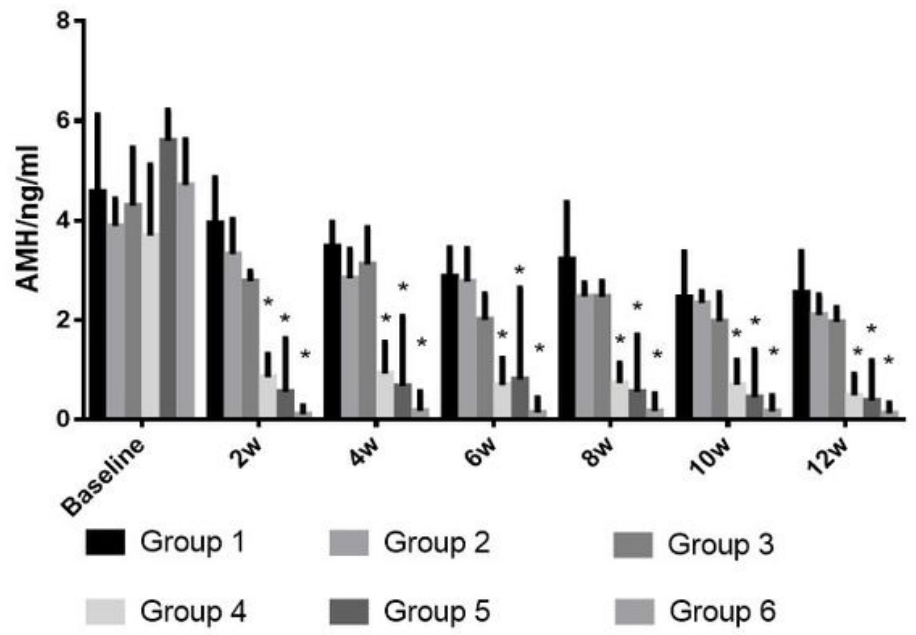

B

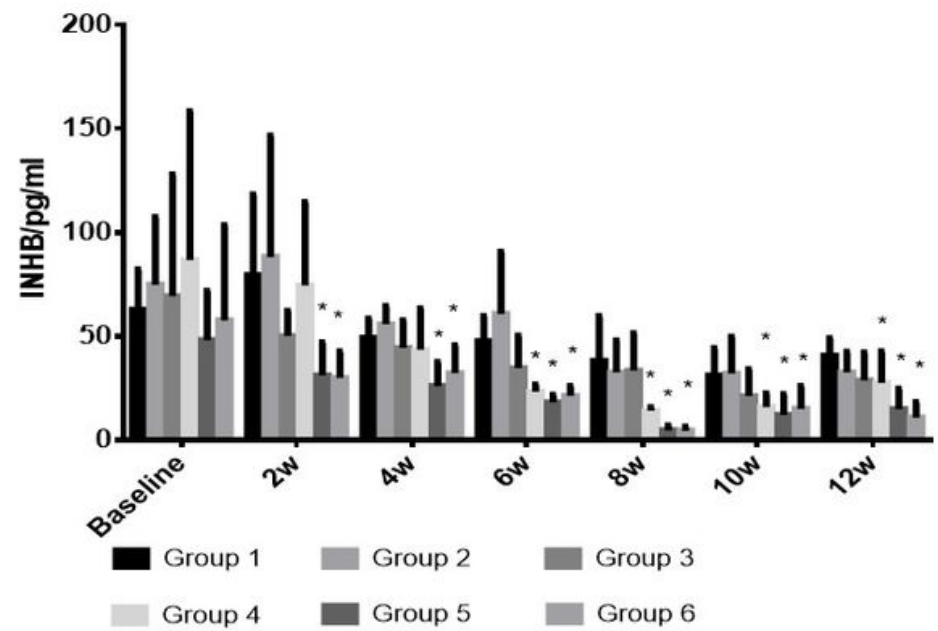

Figure 3

$\mathrm{AMH}$ and INHB levels Larger decrease in ovarian reserve dependent on study duration and degree of tissue excision. (A) Group 4, 5 and 6 had lower AMH levels than Groups $1(\mathrm{P}<.05)$ at 2, 4, 6, 8, 10, 12 weeks after surgery. (B) Group 4, 5 and 6 had lower INHB levels than Group 1(P区.05) at 6, 8, 10, 12 weeks after surgery $\mathrm{AMH}$, Anti-Mullerian hormone; INHB, Inhibin B. 

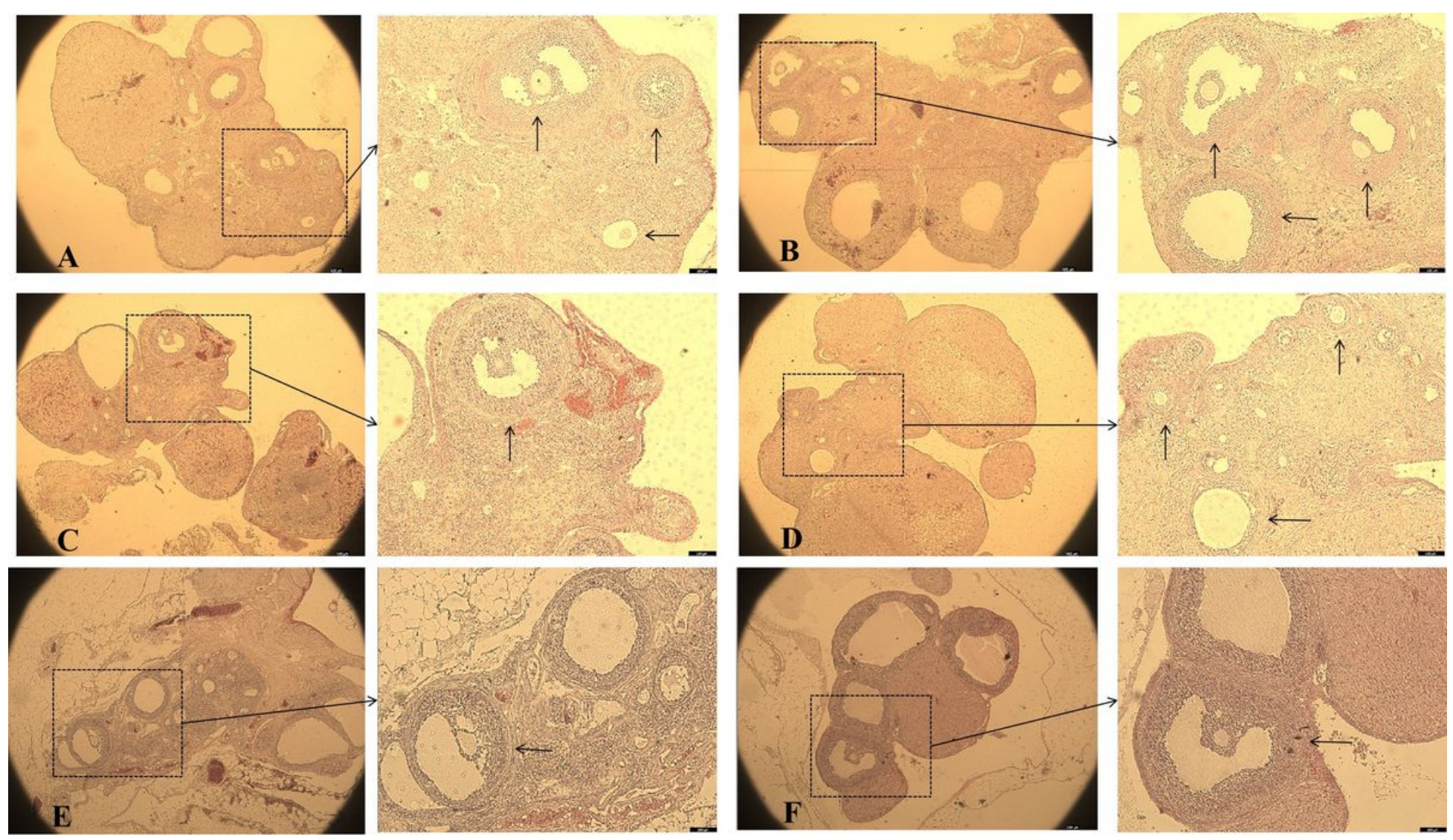

\section{Figure 4}

Morphology of follicles: no differences compared to control The morphological observation of the follicles at day of surgery and 12 weeks after surgery in the group 1-5. (A)Representative histologic images of ovary stained by hematoxylin and eosin at baseline (B) 12 weeks after surgery control group (C) 12 weeks after surgery group 2 (D) 12 weeks after surgery group 3 (E) 12 weeks after surgery group 4 (F) 12 weeks after surgery group 5 Black arrows show follicles. Scale bar equals $100 \mu \mathrm{m}$. The left side of each set of pictures is magnified $40 \mathrm{X}$, and the right side is magnified 100X. 